\title{
Testing the microbial loop concept by comparing mesocosm data with results from a dynamical simulation model
}

\author{
J. G. Baretta-Bekker ${ }^{1}$, B. Riemann ${ }^{2}$, J. W. Baretta ${ }^{1}$, E. Koch Rasmussen ${ }^{1}$ \\ ${ }^{1}$ Ecological Modelling Centre, Joint Department of Water Quality Institute and Danish Hydraulic Institute, Agern Allé 11 , \\ DK-2970 Horsholm, Denmark \\ ${ }^{2}$ The International Agency for ${ }^{14} \mathrm{C}$-Determination, Water Quality Institute, Agern Allé 11, DK-2970 Horsholm, Denmark
}

\begin{abstract}
Data from marine enclosures were compared with model results from the European Regional Seas Ecosystem Model (ERSEM). The simulation runs were performed with the December 1992 (V5.1) version of the pelagic submodel of ERSEM. The aim of the experiment was to verify the microbial loop as implemented in ERSEM against direct observations from marine enclosures. Initial conditions of the state variables for the model runs were derived from the same data. In general, the model results tracked the measured data indicating the model concept and implementation to be realistic. In contrast, the simulated concentrations of nitrate and phosphate in the nutrient-enriched bag stayed higher than observed, indicating the necessity of including mechanisms to allow for luxury uptake in the model description of the phytoplankton. Normalised energy cycles for carbon were established for the control and the enclosure with added nutrients. In the control enclosure respiratory losses from phytoplankton and bacteria were relatively high compared to the nutrient-enriched system, leading to significant differences in the routing of energy through the various microbial loop components without affecting the transfer to mesozooplankton. Although the average levels and changes of several pools and rates were simulated satisfactorily, further model development is certainly needed to predict the functioning of the microbial food web in more detail.
\end{abstract}

KEY WORDS: Microbial loop - Mesocosm - Dynamical simulation model $\cdot$ Ecosystem model Carbon budgets

\section{INTRODUCTION}

More than 4 decades ago, Riley et al. (1949) stated that mathematical models of marine ecosystems should include information on bacteria and scavengers because a substantial amount of the primary production is not utilized in the grazer food chain. Nevertheless, several decades passed before a new paradigm of the production and fate of the primary production was formulated (Pomeroy 1974). Azam et al. (1983) coined the term microbial loop for the set of interacting processes responsible for the (re)cycling of dead organic matter into particulate biomass. Even though it is now generally accepted that microorganisms are responsible for the largest part of the energy flow in the pelagic system (Azam \& Fuhrman 1984, Fenchel 1988), only few studies have been made on ecosystem models including aspects of the microbial loop and the cycling of dissolved organic matter (DOM), which abandoned the classical grazing food chain approach in favour of food webs where trophic interactions are mainly size-dependent.

Pace et al. (1984) described continental shelf food webs as complex webs containing also detritus and protozoa, which was also the approach used in the Ems estuary model (Baretta \& Ruardij 1988). This model extended the complex food web approach to the benthic system.

The model used for this study is the pelagic submodel of the European Regional Seas Ecosystem Model (ERSEM), which again extends the food web approach by also treating the macronutrients as state variables. ERSEM is a complex simulation model, describing the biological and nutrient dynamics, based on first principles of physical, chemical and biological processes and their interactions, with detrital compo- 
nents occupying a central place both in the pelagic and the benthic submodel.

Since carbon and nutrient dynamics are tightly coupled in the microbial loop (e.g. Thingstad 1992), the simulation model includes the macronutrients $\mathrm{NO}_{3}-\mathrm{N}_{\text {, }}$ $\mathrm{NH}_{4}-\mathrm{N}, \mathrm{PO}_{4}-\mathrm{P}$ and $\mathrm{SiO}_{4}$ as well as carbon as state variables and allows $C: N: P$ ratios in the state variables to vary dynamically.

The objective of this study was to test the concept of the microbial loop as implemented in the December 1992 (V5.1) version of the ERSEM model (Baretta \& Ruardij 1991, ERSEM 1993). In the model the concept of the microbial loop is translated into a mathematical description of the microbial loop constituents and their interactions as a set of coupled ordinary differential equations, subjected to abiotic forcing by light and temperature, which was tested, after calibration on data from marine enclosures, against measurements from nutrient-enriched marine enclosures. Preliminary carbon budgets were established calculated from the model output and from direct observations in the enclosures.

\section{MATERIAL AND METHODS}

Enclosure experiments. Experiments were carried out in Knebel Vig, Denmark, in the periods 10 to 31 May and 7 to 31 July 1991. Knebel Vig is a small embayment off the coast of Kalø Vig, which is a part of the Bay of Aarhus. Knebel Vig has a maximum depth of $16 \mathrm{~m}$ and a surface area of $37 \mathrm{~km}^{2}$. Seawater was filled into transparent plastic cylinders (each $1.5 \mathrm{~m}$ in diameter, $3.5 \mathrm{~m}$ deep and with $0.1 \mathrm{~mm}$ thick plastic walls) by 2 divers. The divers pulled the enclosures in a vertical position down to the sediment and filled them by pulling the top part up through the water column. The enclosures were closed just above the sediment surface and fixed to a pontoon bridge. The water in the enclosures was kept in circulation by winddriven mills each connected to a pistil situated $1 \mathrm{~m}$ below the surface (Nybroe et al. 1992).

The water in the enclosures was manipulated in duplicate by adding nutrients $\left(\mathrm{NO}_{3}-\mathrm{N}: 35 \mu \mathrm{M}_{i} \mathrm{PO}_{4}-\mathrm{P}\right.$ : $10 \mu \mathrm{M}_{\text {; }}$ and $\left.\mathrm{SiO}_{4}: 24 \mu \mathrm{M}\right)$ at the start of the experiment. Results from the manipulated enclosures were compared with those from duplicate control enclosures.

Water samples were taken, one every 2 or $3 \mathrm{~d}$, from 3 depths in the enclosures $(0.5,1.5$, and $2.5 \mathrm{~m})$ to cover the vertical profile and the 3 water samples were integrated prior to analyses of biological biomass and activity and chemical constituents. Part of the data integrated into the ERSEM model will be published elsewhere. Below a brief overview of the methodology applied is presented.
Inorganic nutrients: Inorganic phosphate $\left(\mathrm{PO}_{4}-\mathrm{P}\right)$, nitrate $\left(\mathrm{NO}_{3}-\mathrm{N}\right)$, and ammonia were analyzed according to the methods of Murphy \& Riley (1962), Crosby (1967) and Solórzano (1969) respectively. Ammonia reagents were added to samples, standards, and blanks in situ in order to avoid changes caused by storage (Riemann \& Schierup 1978).

Bacteria: Bacterial production was determined in situ by means of ${ }^{3} \mathrm{H}$-thymidine incorporation into trichloroacetic acid precipitate according to Fuhrman \& Azam (1980). A conversion factor of $1.1 \times 10^{18}$ cells $\mu \mathrm{mol}^{-1}$ of thymidine incorporated was applied (Riemann et al. 1987). A conversion factor of $0.35 \mathrm{pg} \mathrm{C}$ $\mu \mathrm{m}^{-3}$ was applied (Bjørnsen 1986) to convert cell volume to carbon. Enumeration of bacteria was carried out using the standard acridine orange technique (Hobbie et al. 1977). Cell volumes were determined from enlarged black and white photographs exposed to a screen (Lee \& Fuhrman 1987). A total of 5 pictures were taken of each filter and 100 cells were measured from each filter.

Heterotrophic nanoflagellates: Grazing by heterotrophic flagellates on bacteria was measured according to Sherr et al. (1987). Fluorescently labelled bacteria (FLB) were prepared from the population of natural bacteria at the experimental site concentrated by tangential flow equipment (Minitan, Millipore). The fraction between 0.1 and $0.8 \mu \mathrm{m}$ net pore size was stained with DTAF and frozen. The labelled bacteria were kept at 5 to $15 \%$ of the number of bacteria in the samples. After incubation in situ for 15 to $20 \mathrm{~min}$, samples were fixed in $0.5 \%$ Lugol's solution and $3 \%$ formaldehyde, filtered onto $0.8 \mu \mathrm{m}$ black Nuclepore filters, and stored at $2^{\circ} \mathrm{C}$. The food vacuoles of 40 to 75 heterotrophic nanoflagellates were examined for content of FLB using epifluorescence microscopy. Grazing rates were based on ingestion of natural bacteria and the number of heterotrophic flagellates. Heterotrophic flagellates were enumerated from proflavin-stained preparations by epifluorescence microscopy (Haas 1982). Cell volumes of 100 flagellates per filter were measured by microscope. Biovolumes were converted to carbon by multiplying by $0.12 \mathrm{pg} \mathrm{C} \mu \mathrm{m}^{-3}$

Zooplankton: Ciliates and zooplankton were identified and counted in Lugol-fixed samples with an inverted microscope and a stereomicroscope respectively. Further details on the applied methodology are reported by Horsted et al. (1988).

Phytoplankton: Primary production was carried out in situ using the ${ }^{14} \mathrm{C}$ technique (Steemann Nielsen 1952). Half-day incubations were carried out using $25 \mathrm{ml}$ Jena bottles added $2 \mu \mathrm{Ci} \mathrm{NaH}{ }^{14} \mathrm{CO}_{3}$ (The International Agency for ${ }^{14} \mathrm{C}$ Determination, Hørsholm. Denmark). Bottles were incubated at 3 depths $(10 \mathrm{~cm}$, $1 \mathrm{~m}$ and $2 \mathrm{~m}$ ) to cover changes in the vertical profile. 


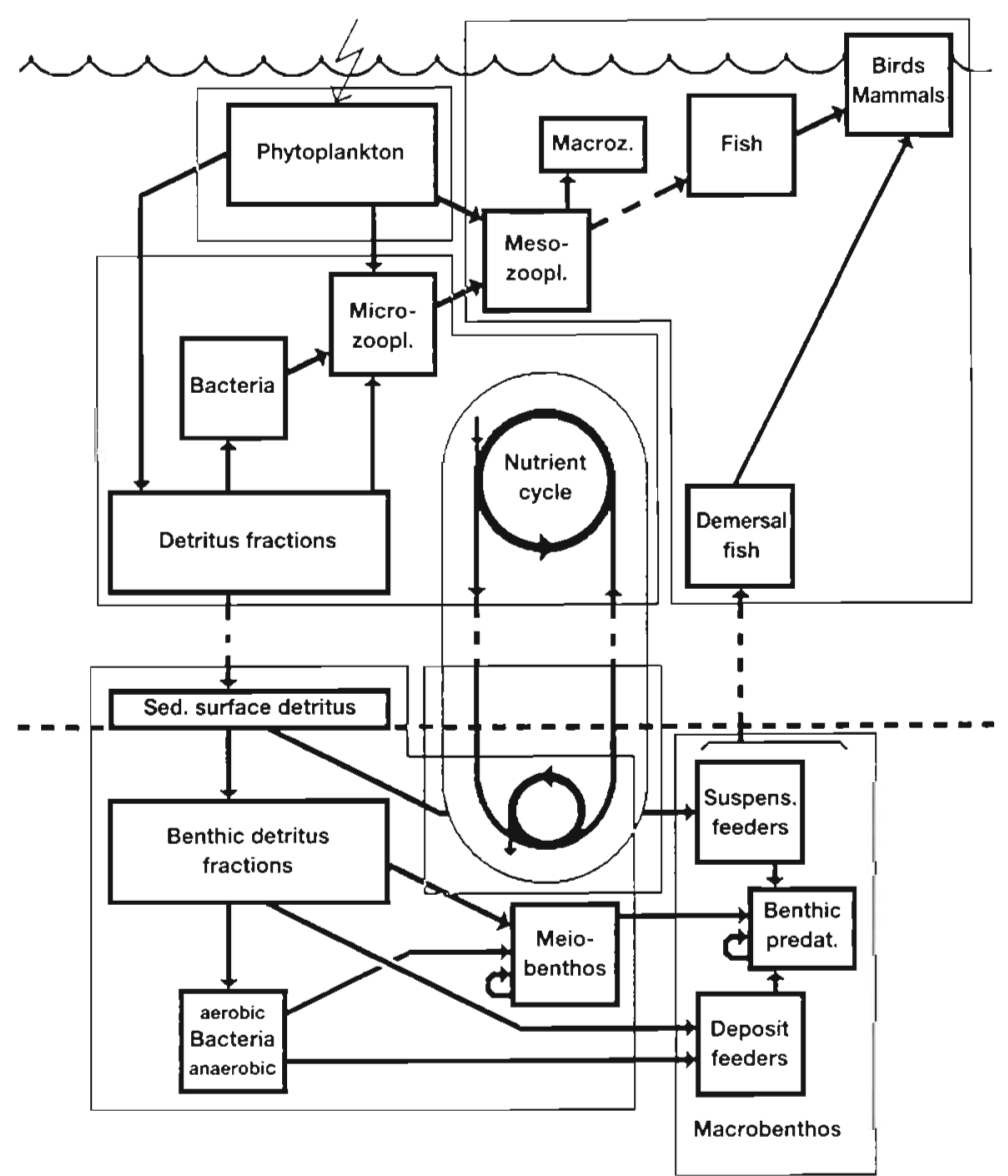

Fig. 1. Flow scheme of the pelagic submodel of the ERSEM column model. Arrows indicate fluxes in carbon and in nutrients; dashed arrows are connections to other ERSEM submodels which were excluded in the simulations of the enclosure experiments
A specific absorption coefficient of $83.4 \mathrm{~g}^{-1}$ $\mathrm{l}^{-1} \mathrm{~cm}^{-1}$ for chlorophyll a (chl a) was applied (Wintermans \& DeMots 1965).

Description of the model. The ERSEM water column model is a model representing the biological and nutrient dynamics in a water column in a temperate shelf sea, which may be thermally stratified, interacting with a benthic system underneath. The model runs on Sun workstations under SunOS (UNIX) within the simulation environment SESAME (Ruardij et al. 1990) and is available from the authors on request.

The pelagic part of the ERSEM column model which was used for the simulation of the enclosure experiments consists of a 2 layered column with the nutrients: phosphate (N1p), nitrate (N3n), ammonia (N4n) and reactive silicate (N5s); the carbon state variables are: diatoms (P1C), flagellate phytoplankton (P2C), carnivorous zooplankton (Z3c), omnivorous zooplankton (Z4C), microzooplankton ( $\mathrm{Z} 5 \mathrm{C}$ ), heterotrophic flagellates (Z6C), pelagic bacteria (B1C) and detritus carbon (R6c) with the associated nutrient state variables (P1p to R6p; P1n to R6n; P1s and R6s). See Fig. 1 for the pelagic food web as modelled in the ERSEM model.

The biological functional groups in the ERSEM model are formulated using the concept of the 'standard organism' (Fig. 2). The universal biological processes of food uptake, respiration, growth, mortality etc. are defined in this concept. The fundamen-
After incubations, samples were filtered through a $20 \mu \mathrm{m}$ mesh net, followed by a $2 \mu \mathrm{m}$ Nuclepore filter, and a $0.45 \mu \mathrm{m}$ Sartorius membrane filter. The filters were treated with fuming $\mathrm{HCl}$ for $5 \mathrm{~min}$. Filters were dissolved in $10 \mathrm{ml}$ Filter Count (Packard), and counted in a scintillation counter (Rack-Beta, LKB Vallac). Results from dark bottles were subtracted from light bottles. The standardization (i.e. radioactivity per $\mathrm{ml}$ or ampoule) was compiled as described by Ursin \& Bresta (1980).

Phytoplankton chlorophyll was measured from duplicate samples filtered onto $25 \mathrm{~mm}$ Whatman GF/C filters and extracted in $96 \%$ ethanol for $20 \mathrm{~h}$ without homogenization (Jespersen \& Christoffersen 1987). The pigment extracts were measured spectrophotometrically without corrections for degradation products.

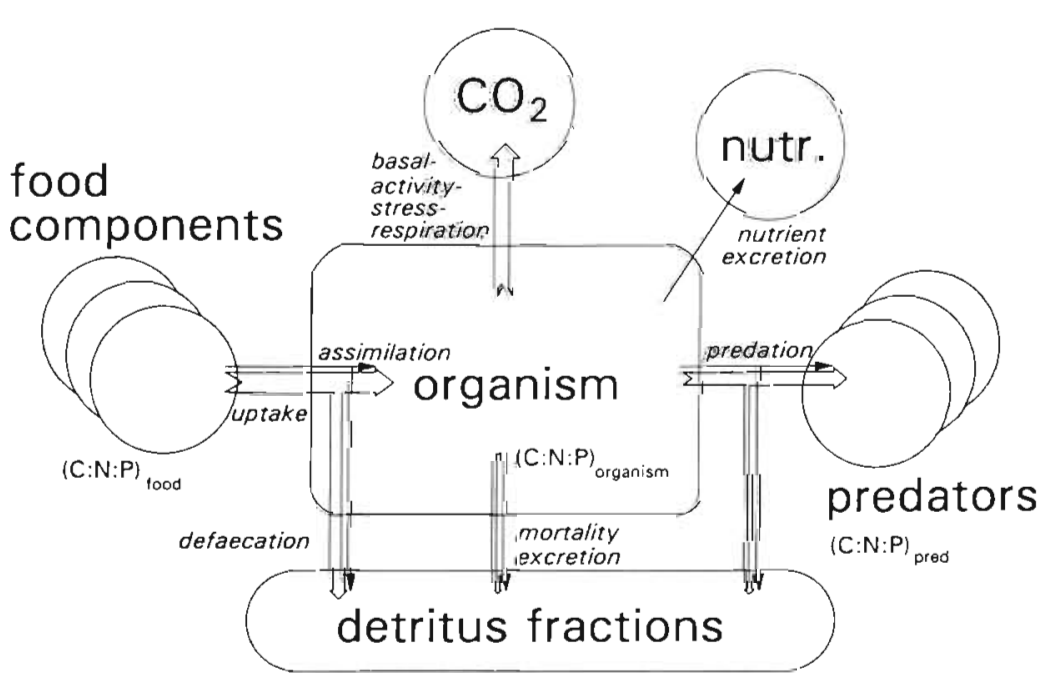

$\longrightarrow$ carbon flux nutrient flux
Fig. 2. Standard organism, used as the basis for modelling the functional groups in ERSEM 
tal equation for net growth of the standard organism is $\mathrm{d} S T_{C} / \mathrm{d} t=[\operatorname{sug} S T-(\operatorname{srt} S T+s d S T+\operatorname{set} S T+s g S T)] \cdot S T_{C}$

where $S T_{C}=$ carbon biomass of the standard organism sugST = specific uptake rate; $s r t S T=$ specific total respiration rate; $s d S T=$ specific mortality rate; set $S T=$ specific total excretion rate; and $s g S T=$ specific grazing rate.

The processes determining the daily standing stock variations are temperature dependent and dependent on the oxygen saturation. The temperature effect is quantified in the following equation:

$$
\text { etST }=q 10 S T S^{(E T W-10) \times 0.1}
$$

where ETW is the water temperature and q10ST\$ is the characteristic temperature coefficient, a statevariable-dependent parameter.
The specific uptake rate of the standard organism (sugST) is dependent on temperature, on the parameter sumSTS and on either rumST, which is the amount of food available, or in the case of autotrophs on sumST, which is the potential photosynthetic activity.

Respiration ( $s r t S T$ ) consists of 2 parts, standing stock respiration and activity respiration. The standing stock respiration is dependent on temperature while the activity respiration is dependent on the uptake rate, on the assimilation efficiency and on the activity excretion.

The mortality rate (sdST) has a temperature-dependent part and a part dependent on the relative oxygen saturation. The excretion rate (setST) is dependent on the uptake rate, on the assimilation efficiency and the activity excretion. The total of mortality and excretion products are partitioned over DOM (R1) and POM (R6) according to the value of the parameter pe_R1ST\$.

Grazing ( $s g S T$ ) is dependent on the amounts of food available to the different predators.

Table 1. Parameters of the microbial loop part of the ERSEM model. P1: diatoms; P2: flagellate phytoplankton; Z5: microzooplankton; Z6: heterotrophic flagellates; B1: pelagic bacteria; R6: detritus. Naming convention: ST, standard organism; S, specific; p. fraction; $u$, uptake; r, respiration; $d$, mortality; e, excretion; $g$. grazing (when it is the second character) or gross (when it is the third character) $t_{1}$ total $_{i} \mathrm{~m}$, maximal $_{i} \mathrm{c}, \mathrm{n}, \mathrm{p}, \mathrm{s}$ (as last character), carbon, nitrogen, phosphorus, silicate; $\$$ denotes a parameter

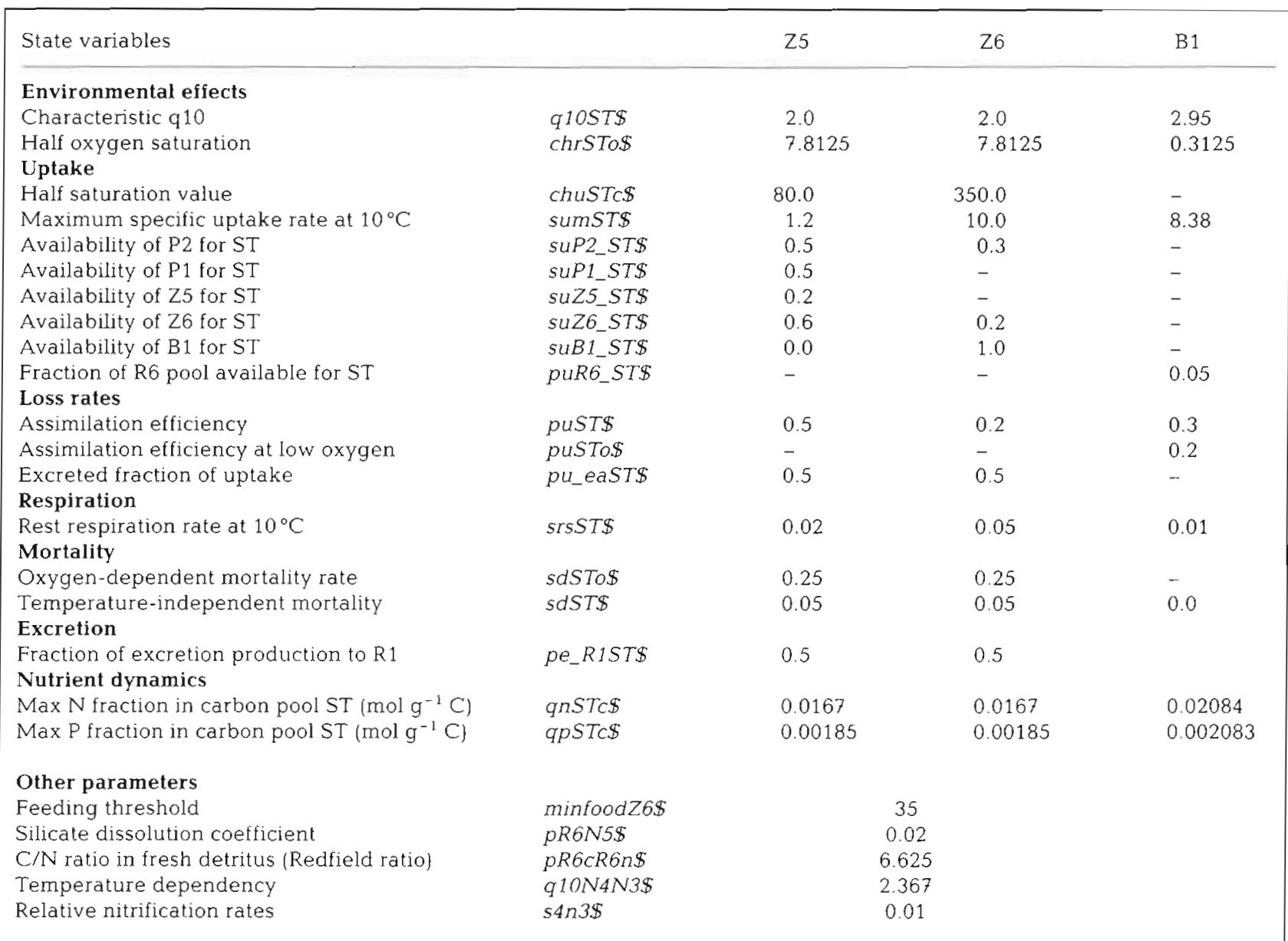


Table 2. Parameters of the primary production module of the ERSEM model. Symbols and naming convention as in Table 1

\begin{tabular}{|c|c|c|c|}
\hline State variables & & P1 & $\mathrm{P} 2$ \\
\hline \multicolumn{4}{|l|}{ Environmental effects } \\
\hline Characteristic q10 & $q 10 S T \$$ & 2.0 & 2.0 \\
\hline \multicolumn{4}{|l|}{ Uptake } \\
\hline Maximum specific uptake rate at $10^{\circ} \mathrm{C}$ & sumSTS & 1.0 & 1.0 \\
\hline \multicolumn{4}{|l|}{ Loss rates } \\
\hline Excreted fraction of uptake & pu_eaST\$ & 0.1 & 0.1 \\
\hline Fr. of activity excreted under nutrient limitation & pum_eoSTS & 0.6 & 0.6 \\
\hline Fraction of lysis products of ST to DOM & peo_R1STS & 0.2 & 0.5 \\
\hline $\begin{array}{l}\text { B1 biomass where lysis doubles due to } \\
\text { proteolytic activity }\end{array}$ & chB1eSTCS & - & 600.0 \\
\hline \multicolumn{4}{|l|}{ Respiration } \\
\hline Rest respiration rate at $10^{\circ} \mathrm{C}$ & srsSTS & 0.1 & 0.2 \\
\hline Activity respiration & pu_raST\$ & 0.1 & 0.025 \\
\hline Activity respiraton under nutrient limitation & pum_roSTS & 0.05 & 0.05 \\
\hline \multicolumn{4}{|l|}{ Nutrient dynamics } \\
\hline Max $N$ fraction in carbon pool ST $\left(\mathrm{mol} \mathrm{g}^{-1} \mathrm{C}\right)$ & qnSTCS & 0.0143 & 0.0157 \\
\hline Max P fraction in carbon pool ST $\left(\mathrm{mol} \mathrm{g}^{-1} \mathrm{C}\right)$ & $q p S T C \$$ & $1.096 \times 10^{-3}$ & $0.612 \times 10^{-3}$ \\
\hline Max Si fraction in carbon pool ST $\left(\mathrm{mol} \mathrm{g}^{-1} \mathrm{C}\right)$ & qSSTCS & 0.01785 & \\
\hline Half value of $\mathrm{PO}_{4}$ limitation & $\operatorname{chSTn} \$$ & 0.5 & 0.5 \\
\hline Half value of $\mathrm{NO}_{3}$ limitation & chSTpS & 0.1 & 0.05 \\
\hline Half value of $\mathrm{SiO}_{4}$ limitation & chSTS\$ & - & 0.3 \\
\hline \multicolumn{4}{|l|}{ Other parameters } \\
\hline Preference for $\mathrm{NH}_{4}$ over $\mathrm{NO}_{3}$ & xpref_N4\$ & 2.0 & \\
\hline
\end{tabular}

The differences between the functional groups mainly lie in the values of the parameters and particularly in the rate constants (Tables $1 \& 2$ ), which are derived experimentally, from the literature or from allometric considerations (Moloney et al. 1991), in the food components on the uptake side and in the predators on the predation side.

Phytoplankton: Diatoms (P1) are assumed to be $>20 \mu \mathrm{m}$ and grazed by microzooplankton (Z5) and omnivorous mesozooplankton. The flagellate phytoplankton (P2) is taken to consist of autotrophic flagellates, including picoflagellates, as single cells ranging up to 20 um. Heteroflagellates (Z6), microzooplankton (Z5) and mesozooplankton feed on the autotrophic flagellates.

Microzooplankton: Microzooplankton (Z5) is defined as heterotrophic planktonic organisms from 20 to $200 \mu \mathrm{m}$ in size, excluding heterotrophic flagellates (Z6) and naupliar/larval stages of larger zooplankton and of benthic organisms. It consists mainly of ciliates, which are filter-feeders, feeding on phytoplankton, (P1 and P2), heterotrophic flagellates (Z6), detritus (R6) and, because the microzooplankton itself is a large and diverse group it also feeds on itself. They are grazed by omnivorous zooplankton (Z4).

Heterotrophic nanoflagellate: Heterotrophic nanoflagellates (Z6) feed on bacteria (B1), autotrophic flagellates (P2) and themselves.

Bacteria: Pelagic bacteria (B1) are assumed to be heterotrophic bacteria in the water column living on dissolved organic matter (DOM) and detritus. They form one of the food sources for the heterotrophic flagellates.

The bacteria are modelled slightly different from the standard organism. The activity respiration is a fixed fraction of uptake, while the standing stock or rest respiration is modelled as for the standard organism.

All dissolved bacterial excretion products are transformed into dissolved organic matter (R1), which is again available as substrate for bacteria in the same time step. The bacterial uptake is the minimum of the potential uptake and the total amount of substrate available. The potential uptake is dependent on temperature, oxygen saturation, the maximum specific uptake rate at $10^{\circ} \mathrm{C}$ (the parameter sumB1\$) and on the bacterial biomass itself, while the total amount of substrate available is the sum of all dissolved excretion and lysis products (R1) produced in the same time step and a fraction of the amount of detritus (R6). The size of this fraction depends on the (varying) $C: N$ ratio in detritus.

Detritus: Detritus (R6) is defined as the particulate part of the excretion products, available as food for bacteria. The rest of the excretion products is dissolved organic matter (R1). R1 is considered as well, but because it is available for bacteria in the same time step as it is produced it is not defined as a state variable. 
Nutrients: Most of the nutrient dynamics are tightly coupled to the carbon dynamics except for the nutrient excretion.

The nutrient excretion by the standard organism is

$$
\begin{array}{ll}
f S T N 1 p=(q p S T C-q p S T C \$) \cdot S T_{C} & \text { (for phosphorus) } \\
\text { fSTNIn }=(q n S T C-q n S T C \$) \cdot S T_{C} & \text { (for nitrate and } \\
& \text { ammonia) }
\end{array}
$$

with the parameters $q p S T c \$$ and $q n S T c \$$ defining the maximum nutrient fraction in the carbon pool in the standard organism and with qpSTc and qnSTc being the actual nutrient fractions in the carbon pool. When the difference between the actual and the maximum nutrient fraction becomes negative nutrients are retained, until the maximum value is reached again.

Setup of the model to simulate the enclosure experiments. Of the 2 layers in the model, the upper layer is considered the experimental enclosure, with no exchange of water and hence of either nutrients or other state variables with the lower layer. The benthic submodel has been switched off. The area and the depth of the simulated column has been adapted to the size of the enclosures. The initial values of the state variables have been estimated from the enclosure data. The measured water temperatures are used as a time series instead of the climatological temperature forcing which otherwise is used in the ERSEM model. In the absence of irradiance data the climatological irradiance for the latitude of the experiments is used.

Because the version of the ERSEM model as used to simulate the enclosure experiments is a non-calibrated one in the first instance, enclosure data were used to find a set of parameters for which the correspondence between the simulation and the measurements for both the control and the nutrient-enriched enclosures gives the most realistic results. The only difference between the simulation of the control and the nutrientenriched enclosure is in the initial values.

Diatom data were extracted from the enclosure data by taking the chlorophyll data for the algal fractions $>20 \mu \mathrm{m}$; it was assumed that the chlorophyll values of the algae fraction between 2 and $20 \mu \mathrm{m}$ correspond to the flagellate fraction. The carbon biomass was measured directly by means of the Redalje \& Laws (1981) procedure using ${ }^{14} \mathrm{C}$ incorporation into chl a (Riemann et al. 1993).

The enclosure ciliate data are used to represent the microzooplankton in the model.

The simulation model defines gross production as assimilation of substrate, or assimilation of dissolved inorganic carbon (DIC) in the case of primary production, while net production is defined as assimilation minus respiration and excretion. The measured bacte- rial production is taken to be net production, while the measured primary production is somewhere between the gross and net production, but probably closer to the net production because of the length of the incubation time.

The first priority has been to reproduce the observed phytoplankton dynamics in parameterising the model, since phytoplankton production is the only source of new organic carbon.

\section{RESULTS}

To establish some measure for the uncertainty in the result, we calculated the deviation from the mean of the measured values from the replicate enclosures (Table 3) and ran the model separately for each enclosure, taking the initial values of the modelled variables in each enclosure as starting values for the model runs. The simulated values were then treated in the same way as the measured values and the deviations from the mean calculated (Table 3). The deviation from the mean in the observed values varied between 0.3 and $33 \%$ and between 1.2 and $33 \%$ in the simulated values. Comparing the measured values from each enclosure with the results of the model run for that enclosure we found overall differences from 12 to $15 \%$ in the control enclosures and from 32 to $47 \%$ in the enclosures with added nutrients.

Here we concentrate on 1 control enclosure and 1 nutrient-added enclosure.

\section{Phytoplankton}

Looking first at the time course of the standing stocks in the control enclosure, phytoplankton was steadily increasing, both in terms of size-fractionated carbon and as chl a. The model reproduces the chl a increase well, but predicts decreasing values towards the end of the experiment, while there is a cluster of high experimental values which suggests a continuing increase (Fig. 3a to c). A possible explanation is that the grazing pressure by the zooplankton is too high in the model.

In the nutrient-enriched enclosure the simulated temporal evolution of diatom biomass agrees with observations, while the observed peak in the flagellate phytoplankton is missing in the simulation (Fig. 4a to c). Fig. 4h shows that the predicted decrease of silicate is rather early and consequently the increase of the diatoms as well.

In the control, the model predicts too low rates of net primary production for the large phytoplankton 
Table 3. Measured and simulated values in the 2 control enclosures and 2 nutrient-added enclosures with mean values and the deviation from the mean (Dev. mean) in \%. Biomasses in $\mathrm{mg} \mathrm{C} \mathrm{m}^{-3}$; production and $\mathrm{grazing}^{\mathrm{rates}}$ in $\mathrm{mg} \mathrm{C} \mathrm{m}^{-3} \mathrm{~d}^{-1}$

\begin{tabular}{|c|c|c|c|c|c|c|c|c|}
\hline \multirow[b]{2}{*}{ Enclosure } & \multicolumn{4}{|c|}{ Measured values } & \multicolumn{4}{|c|}{ Simulated values } \\
\hline & 1 & 2 & Mean & Dev. mean & 1 & 2 & Mean & Dev mean \\
\hline \multicolumn{9}{|l|}{ Control } \\
\hline Phytoplankton & 144.00 & 114.00 & 129.00 & 11.63 & 96.00 & 104.00 & 100.00 & 4.00 \\
\hline Primary production & 58.00 & 66.00 & 62.00 & 6.45 & 79.00 & 85.00 & 82.00 & 3.66 \\
\hline Bacterial production & 21.00 & 12.00 & 16.50 & 27.27 & 10.00 & 9.00 & 9.50 & 5.26 \\
\hline Ciliates biomass & 2.00 & 1.00 & 1.50 & 33.33 & 2.00 & 1.00 & 1.50 & 33.33 \\
\hline Bacteria biomass & 41.00 & 54.00 & 47.50 & 13.68 & 44.00 & 38.00 & 41.00 & 7.32 \\
\hline Het. flag. biomass & 14.00 & 13.00 & 13.50 & 3.70 & 16.00 & 20.00 & 18.00 & 11.11 \\
\hline Grazing on bac. by HNF & 17.00 & 14.00 & 15.50 & 9.68 & 10.00 & 11.00 & 10.50 & 4.76 \\
\hline Overall mean deviation & & & & 15.11 & & & & 9.92 \\
\hline \multicolumn{9}{|l|}{ Nutrient-added } \\
\hline Phytoplankton & 1063.00 & 1465.00 & 1264.00 & 15.90 & 244.00 & 262.00 & 253.00 & 3.56 \\
\hline Primary production & 152.00 & 153.00 & 152.50 & 0.33 & 247.00 & 253.00 & 250.00 & 1.20 \\
\hline Bacterial production & 51.00 & 71.00 & 61.00 & 16.39 & 25.00 & 30.00 & 27.50 & 9.09 \\
\hline Ciliates biomass & 9.00 & 5.00 & 7.00 & 28.57 & 47.00 & 29.00 & 38.00 & 23.68 \\
\hline Bacteria biomass & 83.00 & 150.00 & 116.50 & 28.76 & 44.00 & 36.00 & 40.00 & 10.00 \\
\hline Het. flag. biomass & 35.00 & 20.00 & 27.50 & 27.27 & 32.00 & 46.00 & 39.00 & 17.95 \\
\hline Grazing on bac. by HNF & 37.00 & 31.00 & 34.00 & 8.82 & 35.00 & 46.00 & 40.50 & 13.58 \\
\hline Overall mean deviation & & & & 18.01 & & & & 11.29 \\
\hline
\end{tabular}

('diatoms') (Fig. 3d, e), but this is of little consequence to system dynamics, since the $<20 \mu \mathrm{m}$ phytoplankton ('flagellates') dominates both the standing stock and production. The overall model response to nutrient enrichment -- sharply higher production of both phytoplankton groups - is correct, but the detailed dynamics for the 'diatoms' are not (Fig. $4 \mathrm{~d}$, e).

\section{Nutrients}

In the control enclosure the measured DIP, DIN and reactive silicate concentrations (Fig. $3 f$ to $h$ ) are tracked well by the model, while a major discrepancy between observations and model results exists for the uptake dynamics of $\mathrm{N}$ and $\mathrm{P}$ in the nutrient-enriched mesocosm (Fig. 4f, g). Whereas the model results predict a stabilization of $N$ and $P$ concentrations at rather high levels after an initial decrease, the observations show a steady decline to normal summer levels. This discrepancy is due to the phytoplankton production, which is too low, together with the fact that the model does not allow for luxury uptake of nutrients and other aspects of Droop kinetics (Droop 1973, Nyholm 1978) of which the most important is that phytoplankton carbon growth is dependent on internal nutrient concentrations instead of ambient concentrations. The good correspondence between observed and simulated silicate concentrations suggests that diatoms do not have a mechanism for luxury uptake of silicate.

\section{Bacteria and heteroflagellates}

Bacterial biomass is predicted well by the model for both enclosures (Figs. $5 a$ \& 6a), but bacterial production less so, the model predictions (Figs. 5d \& $6 \mathrm{~d})$ being on the low side. Both the grazing flux to heterotrophic flagellates and the biomass of heterotrophic flagellates (Figs. 5b, e $\& 6 b$, e) seem correctly modelled.

\section{Microzooplankton}

In the control enclosure, simulated microzooplankton standing stock corresponds with the observations, but is overpredicted towards the end of the experiment (Fig. 5b). In nutrient-enriched enclosure, the model predicts, incorrectly, that microzooplankton begins to control the small phytoplankton (Fig. 6b).

\section{Detritus}

The decrease of detrital carbon and particulate organic nitrogen over the duration of the experiment is reproduced by the model, using a sinking rate of $0.3 \mathrm{~m} \mathrm{~d}^{-1}$ (Figs. 5f, g \& 6f, g).

\section{Budgets}

To show the differences in carbon cycling between the nutrient-enriched and the control enclosures, we have summarized all calculated flows as daily average carbon flow budgets, normalized to the average daily gross C assimilation of phytoplankton. 

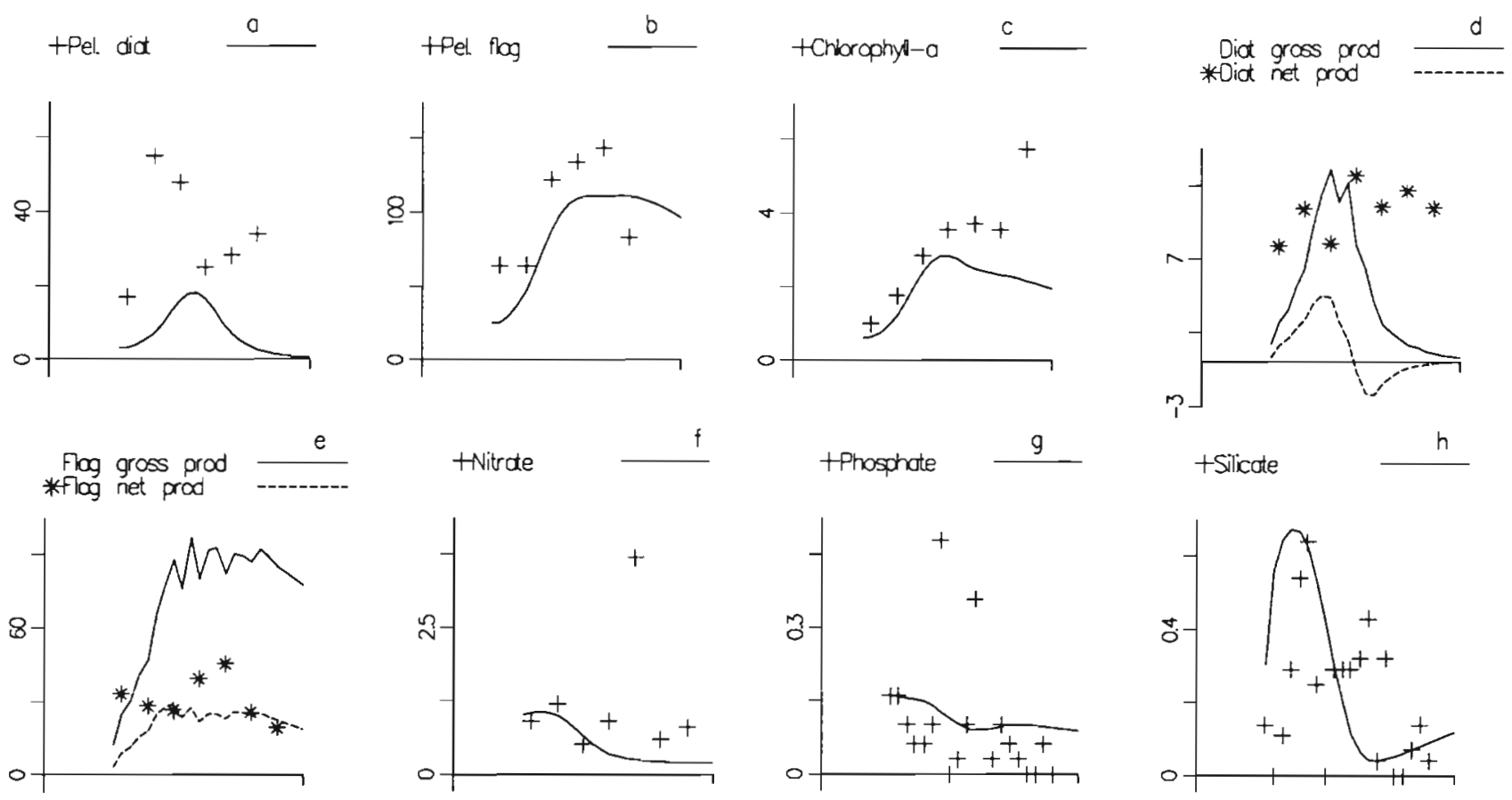

Fig. 3. Simulation output together with enclosure data, measured or calculated from measurements for the control enclosure.

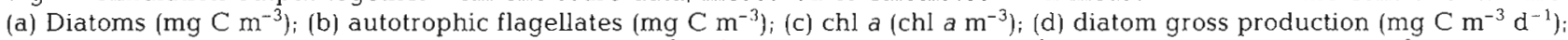
(e) autotrophic flagellate gross production $\left(\mathrm{mg} \mathrm{C} \mathrm{m}^{-3} \mathrm{~d}^{-1}\right)$; (f) nitrate (mmol N $\left.\mathrm{m}^{-3}\right)$; (g) phosphate (mmol $\mathrm{P} \mathrm{m} \mathrm{m}^{-3}$ ); (h) silicate $\left(\mathrm{mmol} \mathrm{Si} \mathrm{m} \mathrm{m}^{-3}\right)$
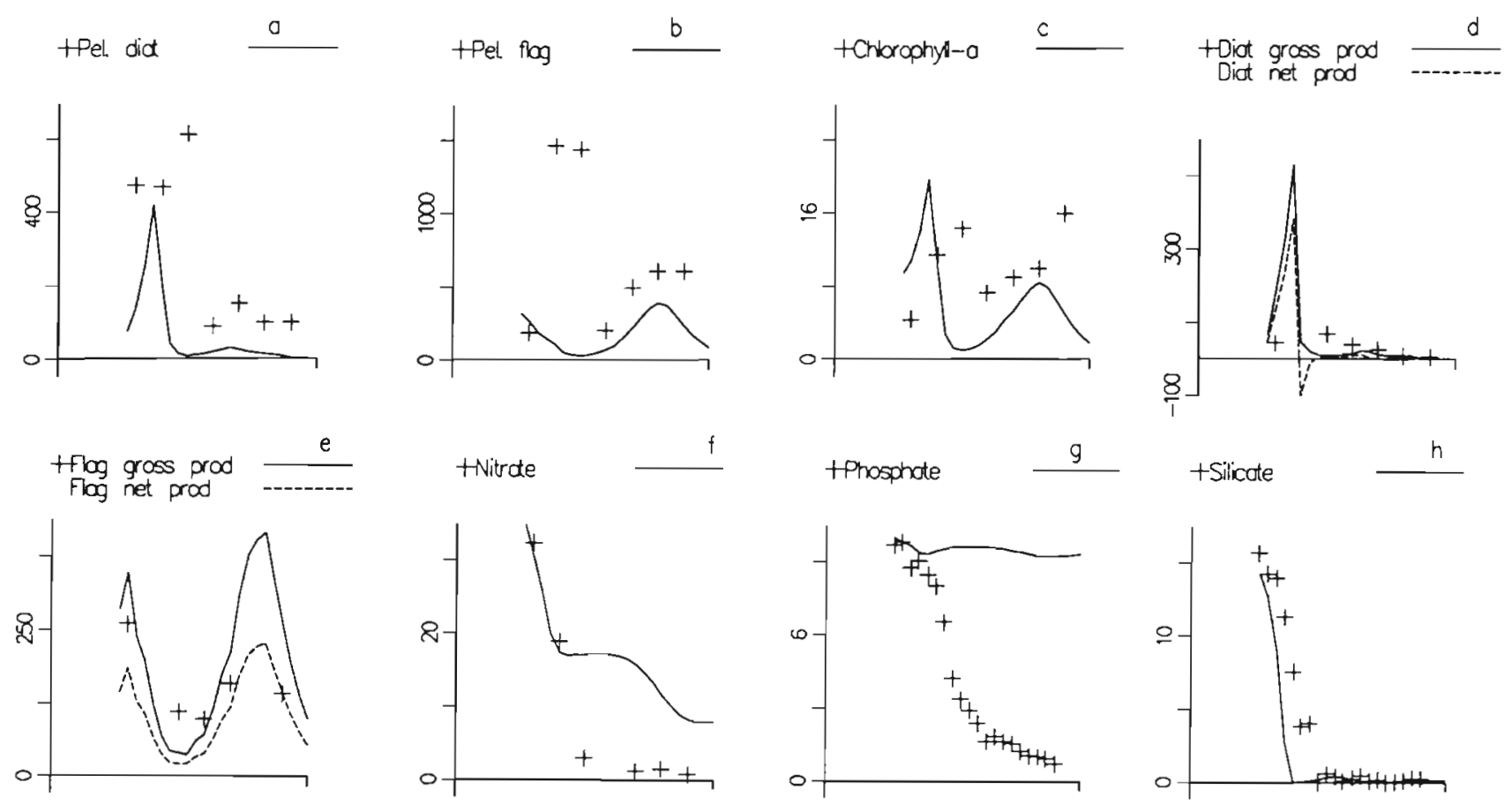

Fig. 4. Simulation output together with enclosure data, measured or calculated from measurements for the nutrient-enriched enclosure. (a) Diatoms ( $\mathrm{mg} \mathrm{C} \mathrm{m}{ }^{-3}$ ); (b) autotrophic flagellates $\left(\mathrm{mg} \mathrm{C} \mathrm{m}{ }^{-3}\right.$ ); (c) chl a ( $\mathrm{chl} \mathrm{a} \mathrm{m}^{-3}$ ); (d) diatom gross production $\left(\mathrm{mg} \mathrm{C} \mathrm{m} \mathrm{m}^{-3} \mathrm{~d}^{-1}\right)_{i}(\mathrm{e})$ autotrophic flagellate gross production $\left(\mathrm{mg} \mathrm{C} \mathrm{m}^{-3} \mathrm{~d}^{-1}\right)_{i}$ (f) nitrate $\left(\mathrm{mmol} \mathrm{N} \mathrm{m}^{-3}\right)$; $(\mathrm{g})$ phosphate (mmol $\left.\mathrm{P} \mathrm{m}^{-3}\right)$;

$$
\text { (h) silicate }\left(\mathrm{mmol} \mathrm{Si} \mathrm{m}^{-3}\right)
$$



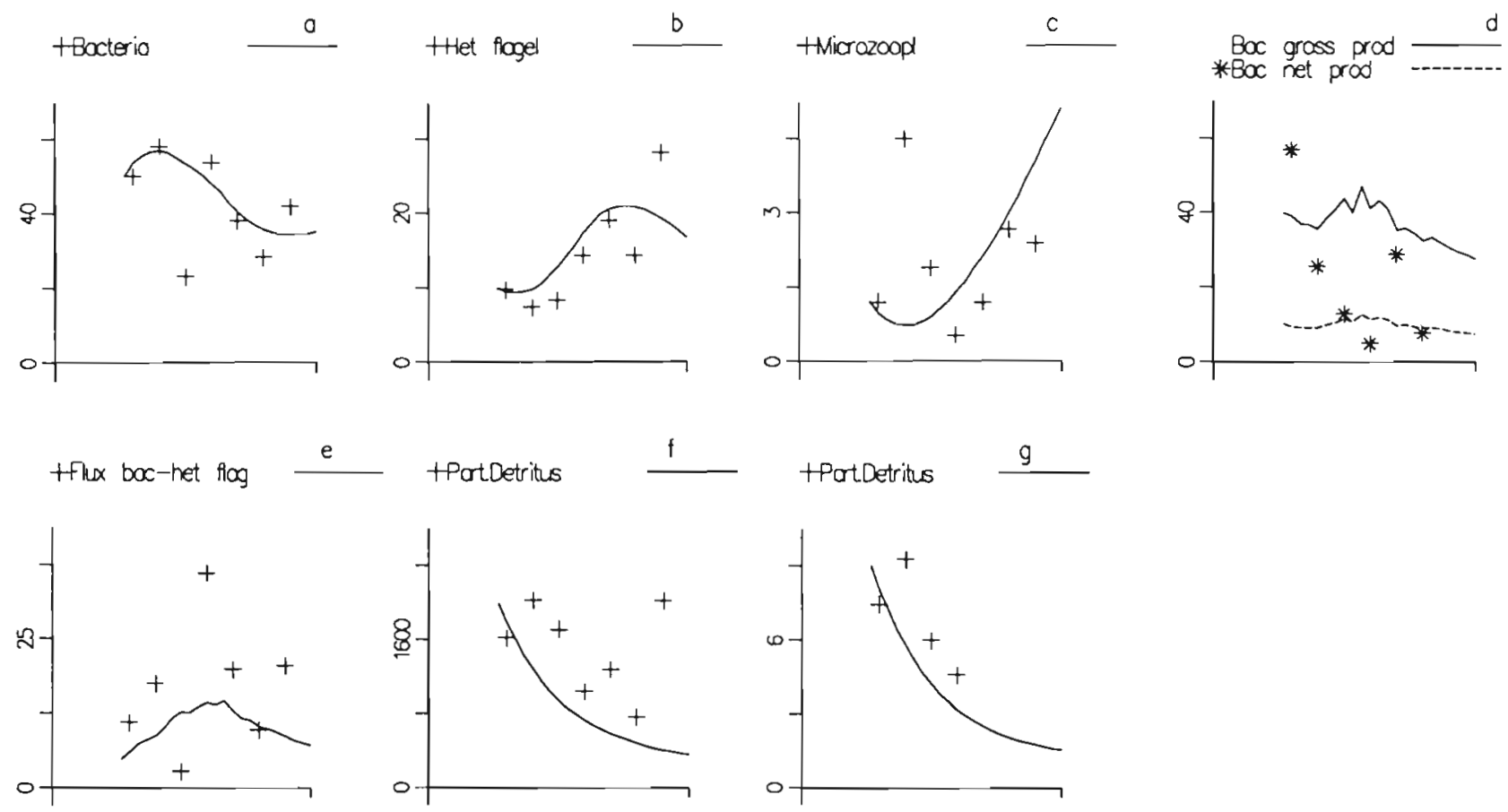

Fig. 5. Simulation output together with enclosure data, measured or calculated from measurements for the control enclosure. (a) Bacteria ( $\mathrm{mg} \mathrm{C} \mathrm{m}^{-3}$ ); (b) heterotrophic flagellates ( $\mathrm{mg} \mathrm{C} \mathrm{m}^{-3}$ ); (c) microzooplankton ( $\mathrm{mg} \mathrm{C}^{-3}$ ); (d) bacteria gross production ( $\mathrm{mg} \mathrm{C} \mathrm{m} \mathrm{m}^{-3} \mathrm{~d}^{-1}$ ); (e) flux from bacteria to heterotrophic flagellates ( $\mathrm{mg} \mathrm{C} \mathrm{m}^{-3} \mathrm{~d}^{-1}$ ); (f) particulate organic carbon (mg $\mathrm{C} \mathrm{m}^{-3}$ ); (g) particulate organic nitrogen ( $\mathrm{mg} \mathrm{N} \mathrm{m}^{-3}$ )
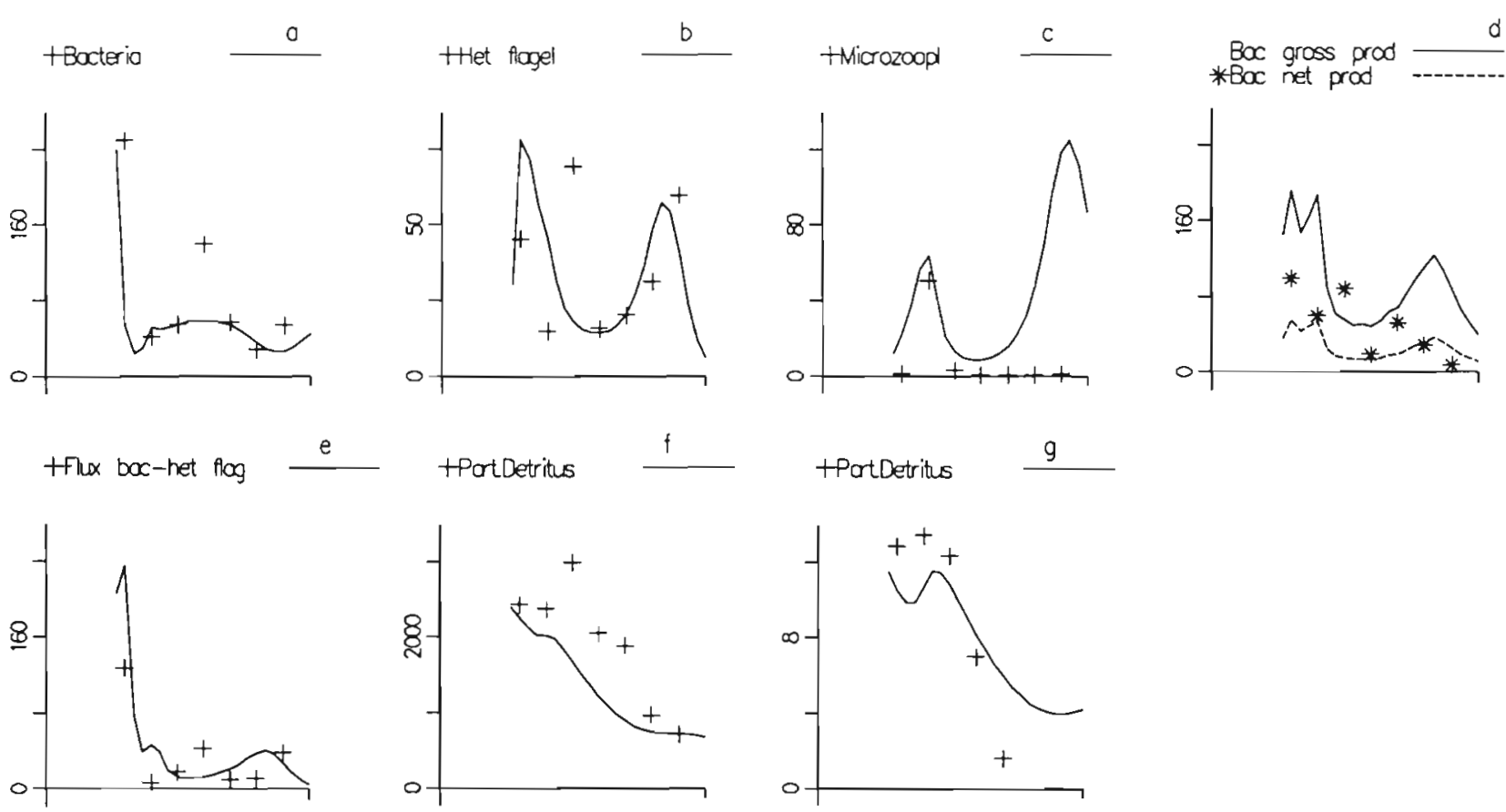

Fig. 6. Simulation output together with enclosure data, measured or calculated from measurements for the nutrient-enriched enclosure. (a) Bacteria (mg C m${ }^{-3}$ ); (b) heterotrophic flagellates ( $\mathrm{mg} \mathrm{C} \mathrm{m} \mathrm{m}^{-3}$ ); (c) microzooplankton (mg C $\mathrm{m}^{-3}$ ); (d) bacteria gross production ( $\mathrm{mg} \mathrm{C} \mathrm{m} \mathrm{C}^{-3} \mathrm{~d}^{-1}$ ); (e) flux from bacteria to heterotrophic flagellates ( $\mathrm{mg} \mathrm{C} \mathrm{m} \mathrm{C}^{-3} \mathrm{~d}^{-1}$ ); (f) particulate organic carbon ( $\left.\mathrm{mg} \mathrm{C} \mathrm{m})^{-3}\right)$ ( $\left.\mathrm{g}\right)$ particulate organic nitrogen $\left(\mathrm{mmol} \mathrm{N} \mathrm{m}{ }^{-3}\right.$ ) 


\section{Measured values}

The distribution of the plankton biomass revealed a dominance of autotrophic biomass and production values in the controls. In the enclosures with added nutrients, a 2 - to 3 -fold increase was observed in all biomass compartments and in the measured production/grazing rates, except for a 4.5 -fold increase in the biomass of the microzooplankton. The average generation times for the phytoplankton were 1.9 and $2.0 \mathrm{~d}$ in the control and in the enclosure with added nutrients respectively, indicating that the nutrient addition did not alter the size structure of the autotrophs. The estimated generation times for the bacteria gave values of 2.1 and $1.6 \mathrm{~d}$. Assuming a growth efficiency of $30 \%$ for the HNF, the estimated generation times were $1.5 \mathrm{~d}$ in the control and $1.7 \mathrm{~d}$ in the enclosures with added nutrients, close to the values for bacteria and algae. The balances between the bacterial net production and the grazing by heterotrophic nanoflagellates suggested that the flagellates consumed all the bacterial production

\section{Predicted values}

In the control enclosure, the predicted carbon budget (Fig. Fa) surprisingly resembled the measured values almost perfectly for the biomasses of the heterotrophic compartments and for the primary production (Table 3). The phytoplankton biomass was well below the measured values, although still within the same order of magnitude. The predicted carbon budget shows mesozooplankton to dominate the direct grazing fluxes, utilizing $14 \%$ of the daily gross primary production, but the indirect transfer of primary production into the microbial loop through dissolved and particulate excretion and lysis products is far larger, with $46 \%$ of the daily gross assimilation cycling through bacteria, providing an additional $0.8 \%$ of the daily gross primary production to the zooplankton. In the control, rates of grazing, respiration, and exudation balance the primary production and maintain the phytoplankton biomass at a low level. Moreover, it is the direct excretion flux from phytoplankton that apparently provides the largest substrate contribution to sustain the bacterial production.

In the enclosure with added mutrients, the model predicted (Fig. 7b), in accordance with the measured values, increases in biomass and production of autotrophs (Table $3 \mathrm{~b}$ ) and in the biomass of zooplankton, microzooplankton, and HNF. However, the general accuracy of the predicted values as compared to direct calculations was lower than in the control enclosure. Thus, the model overestimated the biomass of zooplankton and microzooplankton and underestimated
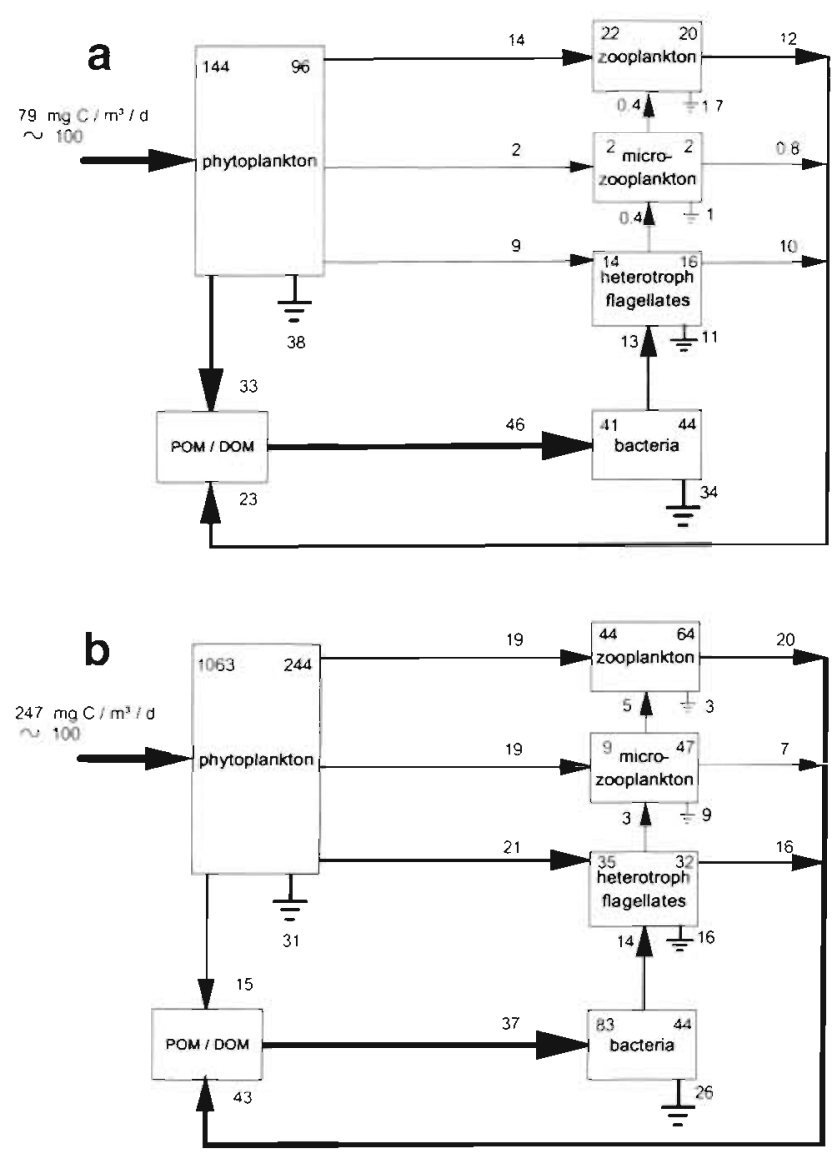

Fig. 7. Normalised carbon flows through the system (a) in the control enclosure and (b) in the nutrient-enriched enclosure. The calculated carbon flows have been normalized to the average daily gross $C$ assimilation of phytoplankton. All other fluxes are given as a percentage of this. Calculated average standing stocks $\left(\mathrm{mg} \mathrm{C} \mathrm{m}^{-3}\right)$ are given in the upper right of the boxes, with the experimentally derived values values given in the upper left of the boxes

the biomass of algae and bacteria. The consequences of the model predictions include that effects of the nutrient addition were seen as an increase in the grazing impact of heterotrophs due to reduced losses from autotrophs via excretion (and a decrease in the importance of the bacteria).

\section{DISCUSSION}

The model discussed here is conceptually very similar to the one of Taylor \& Joint (1990) in terms of the trophic relations between state variables. But whereas Taylor \& Joint (1990) assumed bacteria to be grazed directly by microzooplankton, our model assumes heterotrophic flagellates to be the link between bacteria and microzooplankton. Another major difference between the 2 models is that we discern diatoms and flagellate phytoplankton because we want to track sil- 
icate dynamics as well as $\mathrm{N}$ and $\mathrm{P}$. A central conclusion in their paper was that the microbial loop had little influence on higher trophic levels, since MWE (microbial web efficiency), defined as

microbial grazer production consumed by (macro)zooplankton primary + bacterial production consumed by microbial grazers

was low, ranging from 5 to $10 \%$.

Our model results fall within this range, the control enclosure only having an MWE of $3 \%$ and the nutrient-enriched enclosure having an MWE of $9 \%$, indicating a minor increase in MWE from oligotrophic to eutrophic conditions. This trend is in accordance with the scenario reported from lakes (Riemann \& Christoffersen 1993), from previous observations in marine enclosures with additions of inorganic nutrients (Riemann et al. 1990), and from the measured values in our nutrient-enriched enclosure (Fig. $7 \mathrm{~b}$ ). It should be noted, however, that the short experimental time does not allow us to evaluate the potential role of the mesozooplankton as grazers on algae and heterotrophs because of their slow numerical response.

Our formulation in the model of the functional groups as 'organisms' (Baretta \& Ruardij 1988) allows the functional groups to adapt their physiological rates to changing environmental circumstances. We see this reflected in the lower loss rates to respiration/excretion under nutrient-enriched conditions (budgets). There is a striking reduction in the release of DOC by phytoplankton, which is in agreement with the observation of Joiris et al. (1982) of an inverse relationship between exudation and inorganic- $\mathrm{N}$ concentrations. However, the heterotrophic variables also generate DOC (Jumars et al. 1989), compensating the lower exudation by primary producers. In the model, we have assumed that all exudation/excretion of DOC is immediately available to microbial degradation. In view of recent experimental evidence (Middelboe et al. 1992) this may be too optimistic and also implies a too high growth-yield.

It probably is more correct to take into account the varying $C: N$ and $C: P$ ratio in the DOC as determining the degradability of DOC. Integrating the cycling of $\mathrm{C}$, $\mathrm{N}$ and $\mathrm{P}$ in the microbial food web is central to understand the dynamics of ecosystem behaviour and any consequences of perturbations in the forcing of such systems. A careful monitoring of the temporal evolution of the C:N:P ratio in DOC in enclosures would allow a better quantification of the role of the DOC in fuelling the microbial loop.

As Thingstad (1992) points out, the lack of knowledge of the sources and mechanisms producing organic material available for bacterial growth is a crucial handicap in formulating an accurate mathematical
Table 4. Comparison of fluxes in the nutrient-enriched enclosure ( $\%$ of primary production) calculated in this study with data from Weisse et al. (1990)

\begin{tabular}{|lcc|}
\hline & This study & $\begin{array}{c}\text { Weisse et al. } \\
(1990)\end{array}$ \\
\hline Phytoplankton respiration & 31 & 30 \\
Carbon $\rightarrow$ bacteria & 37 & 36 \\
Phytoplankton excretion & 15 & 10 \\
Carbon $\rightarrow$ HNF & $14(+21)$ & $<5$ \\
Carbon $\rightarrow$ ciliates & 22 & $18(+?)$ \\
Bacterial respiration & 26 & 29.7 \\
\hline
\end{tabular}

model of the microbial loop. Crucial, since the amount determines the quantitative importance of the bacterial link, the source determines the conditions under which it will be produced and the composition determines whether the bacteria are net producers or consumers of inorganic nutrients.

Comparing the carbon budget calculated from the model results for the nutrient-enriched enclosure with the carbon budget given by Weisse et al. (1990) for a spring bloom in Lake Constance (western Europe), there is a surprising similarity in the relative energy flows (as \% of the primary production) between the 2 budgets (Table 4 )

Especially the close correspondence between the relative phytoplankton loss rates is encouraging, since there is a large uncertainty as to what the appropriate values for the dark- and photorespiration parameters should be.

The general correspondence in the relative energy flows in a freshwater and a marine system during a period of abundant nutrient supply indicates that the microbial loop adjusts itself dynamically in a predictable way to similar environmental forcing and that our simulation model in its present state contains the necessary mechanisms and trophic interactions to broadly reproduce this adjustment.

Though the agreement between model results and observations still leaves much room for improvement, it is encouraging that the broad features of both the nutrient-enriched system and the control can be reproduced, because it indicates that the model contains the essential mechanisms and processes to simulate the consequences of nutrient enrichment for system behaviour.

Acknowledgements. This study was partly tunded by the European Community through MAST contract CT90-0021 for J.G.B.-B., J.W.B. and E.K.R. For B.R. this study was supported by the EC MAST program, contract no. CT90-0020 and by the Danish Natural Science Research Council, Danish Technical Research Council (J.no. 11-8630 and 16-4806), and National Agency of Environmental Protection (HAV90 contract 1.23). 


\section{LITERATURE CITED}

Azam, F., Fenchel, T., Field, J G., Gray, J. S., Meyer-Reil, L.-A., Thingstad, F. (1983). The ecological role of watercolumn microbes in the sea. Mar. Ecol. Prog. Ser, 10: $257-263$

Azam, F., Fuhrman, J. A. (1984). Measurements of bacterioplankton growth in the sea and its regulation by environmental conditions. In: Hobbie, J. E., Williams, P. J. LeB. (eds.) Heterotrophic activity in the sea. Plenum Press, New York, p. 179-196

Baretta, J. W., Ruardij, P. (eds.) (1988). Tidal flat estuaries. Ecological studies 71. Springer-Verlag, Berlin, p. 1-353

Baretta, J. W., Ruardij, P. (1991). North Sea modelling. In: Herman, P. M. J., Heip, C. H. R. (eds.) Modelling the benthos. Report of Cost 647. CEC (Commission of the European Communities), p. 31-43

Bjørnsen, P. K. (1986). Automatized determination of bacterioplankton biomass by image analysis. Appl. environ. Microbiol. 51: 1199-1204

Crosby, N. T. (1967). The determination of nitrite in water using Cleve's acid. Proc. Soc. Water Treat. Exam. 16: 51

Droop, M. R. (1973). Some thoughts on nutrient limitation in algae. J. Phycol. 9: 264-272

ERSEM (1993). An overview of the European Regional Seas Ecosystem Model (ERSEM). In: Barthel, K.-G., BohleCarbonell, M., Fragakis, C., Weydert, M. (eds.) Marine sciences and technologies. MAST days and Euromar market, Vol. I. Office for Official Publications of the European Communities, Luxembourg, p. 339-354

Fenchel, T. (1988). Marine plankton food chains. A. Rev. Ecol. Syst. 19: 19-38

Fuhrman, J. A., Azam, F. (1980). Bacterioplankton secondary production estimates for coastal water of the British Columbia, Antarctica, and California. Appl. environ. Microbiol. 39: 1086-1095

Haas, L. W. (1982). Improved epifluorescence microscopy for observing plankton microoorganisms. Annls Inst. Océanogr., Paris 58: 261-266

Hobbie, J. E., Daley, R. J., Jasper, S. (1977). Use of nuclepore filters for counting bacteria by fluorescence microscopy. Appl. environ. Microbiol. 33: 1225-1228

Horsted, S. J., Nielsen, T. G., Riemann, B., Pock-Steen, J. Bjornsen, P. K. (1988). Regulation of zooplankton by suspension-feeding bivalves and fish in estuarine enclosures Mar. Ecol. Prog. Ser. 48: 217-224

Jespersen, A.-M., Christoffersen, K. (1987). Measurements of chlorophyll-a from phytoplankton using ethanol as extraction solvent. Arch. Hydrobiol. 109: 445-454

Joiris, C., Billen, G., Lancelot, C., Daro, M. H., Mommaerts, J. P., Bertels, A., Bossicart, M., Nijs, J., Hecq, J. H. (1982). A budget of carbon cycling in the Belgian coastal zone: relative roles of zooplankton, bacterioplankton and benthos in the utilization of primary production. Neth. J. Sea Res. 16: 260-275

Jumars, P. A., Penry, D. L., Baross, J. A. Perry, M. J., Frost, B. W. (1989). Closing the microbial loop: dissolved organic carbon pathway to heterotrophic bacteria from incomplete ingestion, digestion and absorption in animals. Deep Sea Res. 36: 483-495

Lee, S., Fuhrman, J. A. (1987). Relationships between biovolume and biomass of naturally derived marine bacterioplankton. Appl. environ. Microbiol. 53: 1298-1303

Middelboe, M., Nielsen, B., Søndergaard, M. (1992). Bacterial utilization of dissolved organic carbon (DOC) in coastal waters - determination of growth yield. Arch. Hydrobiol. Beih. Ergeb. Limnol. 37: 51-61

Moloney C. L., Field, J. G., Lucas, M. I. (1991). The size-based dynamics of plankton food webs. II. Simulations of three contrasting southern Benguala food webs. J. Plankton Res. 13: $1039-1092$

Murphy, I., Riley, J. P. (1962). A modified single solution method for the determination of phosphate in natural waters. Analytica chim. Acta 27: 21-26

Nybroe, O., Christoffersen, K. Riemann, B. (1992). Survival of Bacillus licheniformis in seawater model ecosystems. Appl. environ. Microbiol. 58: 252-259

Nyholm, N. (1978). A simulation model for phytoplankton growth cycling in eutrophic shallow lakes. Ecol. Modelling 4: $279-310$

Pace, M. L., Glasser J. E., Pomeroy, L. R. (1984). A simulation analysis of continental shelf food webs. Mar. Biol. 82: 47-63

Pomeroy, L. R. (1974). The ocean's food web, a changing paradigm. BioSci. 24: 499-504

Redalje, D. G., Laws, E. A. (1981). A new method for estimating phytoplankton growth rates and carbon biomass. Mar. Biol. 62: 73-79

Riemann, B., Bjørnsen, P. K., Newell, S., Fallon, R. D. (1987). Calculation of cell production of coastal marine bacteria based on incorporation of ${ }^{3} \mathrm{H}$-thymidine. Limnol. Oceanogr. 32: 471-475

Riemann, B., Christoffersen, K. (1993). Microbial trophodynamics in temperate lakes. Mar. microb. Food Webs 7 : $69-100$

Riemann, B., Lignell, R., Laws, E. (1993). Time-course development of ${ }^{14} \mathrm{C}$ specific activity of chlorophyll- $a_{1}$ carbon and proteins in algal cultures. Limnol. Oceanogr. 38: 96-111

Riemann, B., Schierup, H.-H. (1978). Effects of storage and conservation on the determination of ammonia in water samples from four lake types and a sewage plant. Wat. Res. 12: 849-853

Riemann, B., Sørensen, H. M., Bjørnsen, P. K., Horsted, J. S. Jensen, L. M., Nielsen, T. G., Sondergaard, M. (1990). Carbon budgets for the microbial food web in estuarine enclosures. Mar. Ecol. Prog. Ser. 65: 159-170

Riley, G. A., Stommel, H., Bumpus, D. F. (1949). Quantitative ecology of the plankton of the western North Atlantic. Bull. Bingham oceanogr. Coll. 12: 1-169

Ruardij, P., Baretta, J W., Baretta-Bekker, J. G. (1990). SESAME, a Software Environment for the Simulation and Analysis of Marine Ecosystems. Manuals. Netherlands Institute for Sea Research, Texel

Sherr, B. F., Sherr, E. B., Fallon, R. D. (1987). Use of mono-dispersed, fluorescently labelled bacteria to estimate in situ protozoan bacterivory. Appl. environ. Microbiol. 53: $958-965$

Solórzano, L. (1969). Determination of ammonia in natural waters by the phenolhypochlorite method. Limnol. Oceanogr. 14: 799-801

Steemann Nielsen, E. (1952). The use of radioactive carbon $\left({ }^{14} \mathrm{C}\right)$ for measuring organic production in the sea. J. Cons perm. int. Explor. Mer 18: 117-140

Taylor, A. H., Joint, I. (1990). A steady-state analysis of the 'microbial loop' in stratified systems. Mar. Ecol. Prog. Ser. 59: $1-17$

Thingstad, T F. (1992). Modelling the microbial food web structure in pelagic ecosystems. Arch. Hydrobiol. Beih. Ergeb. Limnol. 37: 111-119

Ursin, C., Bresta, A. M. (1980). On the application of the liquid scintillation counting of ${ }^{14} \mathrm{C}$-labelled phytoplankton. Comm. Meet. int. Coun. Explor. Sea. C.M.-ICES/L: 31

Weisse, T., Müller, H., Pinto-Coelho, R. M., Schweizer, A., Springmann, D., Baldringer, G. (1990). Response of the microbial loop to the phytoplankton spring bloom in a large prealpine lake. Limnol. Oceanogr. 35: 781-794

Wintermans, F G. M., DeMots, A. (1965). Spectrophotometric characteristics of chlorophylls $a$ and $b$ and their pheophytins in ethanol. Biochim. biophys. Acta 109: 448-453 